\title{
Biosynthesis of Fatty Acids by Lactating Human Breast Epithelial Cells: An Evaluation of the Contribution to the Overall Composition of Human Milk Fat
}

\author{
BETTY J. THOMPSON AND STUART SMITH \\ Bruce Lyon Memorial Research Laboratory, Children's Hospital Medical Center of Northern California, \\ Oakland, California 94609
}

\begin{abstract}
The objective of this study was to characterize the fatty acid biosynthetic pathway of the lactating human breast. Mixed cell populations, obtained by centrifugation of human milk, were enriched in breast epithelial cells by a selective adsorption procedure. Confirmation of the identity of the breast epithelial cells was obtained immunohistochemically. These viable breast epithelial cells incorporated radioactively labeled acetate predominantly into fatty acids with less than $16 \mathrm{C}$ atoms. The presence of the two key enzymes characteristic of the medium-chain fatty acid biosynthetic pathway of nonruminants, fatty acid synthetase, and thioesterase II, was demonstrated both qualitatively, by immunohistochemistry, and quantitatively, by enzyme assay. The results indicate that the lipogenic system of the human breast is qualitatively very similar to that of rats, mice, and rabbits, which also secrete milk fats containing medium-chain fatty acids. Quantitatively, however, the mammary fatty acid biosynthetic pathway appears to be less active in humans than in these other species. (Pediatr Res 19: 139-143, 1985)
\end{abstract}

The presence of breast epithelial cells in human milk was first reported more than a quarter century ago (10). Although a number of investigators have been successful in culturing these cells $(3,5,12,17,26,27,34)$, it appears that, to date, no serious attempt has been made to utilize such cells in studying metabolic and enzymological characteristics of the lactating human breast. We have recently attempted to use these cells in the study of the fatty acid biosynthetic pathway.

Work in our laboratory with rodents has demonstrated that the mammary epithelium of these animals is uniquely able to synthesize the medium-chain fatty acids characteristic of milk fat $(1,21,28)$. We and others $(13-15,19,31,32)$ have shown that the unique product specificity of the mammary gland lipogenic system in nonruminant mammals is attributable to the presence in the epithelium of a tissue-specific chain-terminating enzyme, medium-chain fatty acyl-S-4'-phosphopantetheine-fatty acid synthetase thioester hydrolase (trivial name, thioesterase II).

Received December 14, 1983; accepted August 15, 1984.

Correspondence to Dr. Stuart Smith. Bruce Lyon Memorial Research Laboratory, Children's Hospital Medical Center, 51 and Grove Streets, Oakland, CA 94609.

This work was supported in part by Grants HD 12588 and RR 05467 from the National Institutes of Health and a Postdoctoral Research Fellowship [B.J.T.] from the American Heart Association, California Affiliate.
The objective of this study was initially to ascertain whether epithelial cells obtained from human milk could be used to study the lipogenic pathway, to determine whether the pathway resembled that already established for nonruminants and to assess the contribution of the pathway to the overall production of human milk fat.

\section{MATERIALS AND METHODS}

Subjects. The age of the donors ranged from 26-36 yr and the stage of lactation ranged from 1-15 months. No attempt was made to differentiate between subjects on the basis of diet, age, stage of lactation, etc. Milk was collected by manual expression, transferred to a plastic tube and maintained at $4^{\circ} \mathrm{C}$ during transportation to the laboratory for processing.

Preparation of breast epithelial cells. Milk was equilibrated to room temperature and then centrifuged at $500 \times g$ for $10 \mathrm{~min}$. The resulting pellet was resuspended in Krebs-Henseleit bicarbonate buffer containing $1 \%(\mathrm{w} / \mathrm{v})$ bovine serum albumin and $10 \mathrm{mM}$ glucose. The cells were washed three times by resuspension and centrifugation. Usually, a portion of the final cell suspension was taken for a cell count and/or immunohistochemical characterization. For enrichment of epithelial cells, the cell suspension $(2 \mathrm{ml})$ was transferred to a glass scintillation vial $(20$ $\mathrm{ml}$ capacity) and the atmosphere flushed with $\mathrm{O}_{2} / \mathrm{CO}_{2}(19: 1)$. The vial was maintained at $37^{\circ} \mathrm{C}$ for $2 \mathrm{~h}$ at which time portions were removed for a cell count, for immunohistochemistry and, where appropriate, for utilization in metabolic or enzymatic studies. Viability of the cells was assessed by the trypan blue exclusion technique and cell number was estimated with a hemocytometer.

Immunohistochemical characterization of cells. Cells were fixed in formalin, washed with ethanol and acetone, and stained as described elsewhere (20). Staining for human breast epithelial cell surface antigens was achieved using a first layer of rabbit antihuman milk fat globule membrane antibodies and a second layer of fluoresceinated goat antirabbit IgG antibodies. For staining of fatty acid synthetase and thioesterase II, the primary antibodies used were rabbit antihuman fatty acid synthetase and rabbit anti-rat thioesterase II, respectively. Antihuman milk fat globule membrane antibodies were raised in rabbits and purified by affinity chromatography (4). The antibodies recognize surface differentiation antigens unique to human mammary epithelial cells (4). Rabbit antibodies were also raised to highly purified human fatty acid synthetase (35) and rat thioesterase II (32). The antifatty acid synthetase antibodies, purified by ammonium sulfate precipitation and chromatography on DEAE-cellulose, gave a single immunoprecipitin line when diffused against a cytosol 
prepared from a human breast epithelial cell line (35). Antirat thioesterase antibodies were purified by affinity chromatography on Sepharose-antigen columns, essentially as recommended by Pharmacia, Uppsala, Sweden. Evidence that these antibodies were monospecific for thioesterase II was obtained by Ouchterlony double-diffusion analysis (32). A detailed analysis of the specificity of the antirat thioesterase II antibodies and their crossreactivity with human thioesterase II has been presented elsewhere (33).

Lipogenesis. Cell suspensions (actual cell number ranged from $0.3-20$ million cells) were incubated for $2 \mathrm{~h}$ at $37^{\circ} \mathrm{C}$ under an atmosphere of $\mathrm{O}_{2} / \mathrm{CO}_{2}(19: 1)$ in plastic tubes containing $1 \mathrm{ml}$ of Krebs-Henseleit bicarbonate buffer, $\mathrm{pH} 7.4$, supplemented with $20 \mathrm{mM}$ glucose, $20 \mathrm{mM}$ sodium $\left[1-{ }^{14} \mathrm{C}\right]$ acetate $(100 \mu \mathrm{Ci})$, and $1 \%(\mathrm{w} / \mathrm{v})$ bovine serum albumin. Reactions were stopped by sedimenting the cells at $600 \times g$ for $5 \mathrm{~min}$ in a centrifuge. The supernatant was discarded and the cell pellet was disrupted in $1.5 \mathrm{ml}$ of hexane/propan-2-ol $(3: 2 \mathrm{v} / \mathrm{v})$ in a Polytron homogenizer. Lipids were extracted and saponified and the fatty acids were isolated (24). Radioactivity in a portion of the extract was determined by liquid scintillation spectrometry (32) and the remainder of the sample was subjected to gas-liquid radiochromatography. Lipogenic rate was directly proportional to the number of cells incubated. Results were calculated on a "per cell" basis.

Gas-liquid chromatography. Analysis of radioactive and nonradioactive samples was carried out on an instrument described previously in detail (2). Free fatty acids were chromatographed on a column $\left(5 \mathrm{ft} \times 1 / 8\right.$ in) of $10 \% \mathrm{HI}-\mathrm{EFF}, 3 \% \mathrm{H}_{3} \mathrm{PO}_{4}$ on Anakrom Q (60/70); a carrier gas flow of $\mathrm{Ar}^{-\mathrm{CO}_{2}}$ (19:1) was maintained at $25 \mathrm{ml} / \mathrm{min}$ and the oven temperature was programed from $70-212^{\circ} \mathrm{C}$ at $4^{\circ} \mathrm{C} / \mathrm{min}$. In some experiments, where resolution of saturated and unsaturated fatty acids was required, methyl esters, prepared with $\mathrm{BF}_{3} / \mathrm{MeOH}$ (18), were chromatographed on a column $(6 \mathrm{ft} \times 1 / 8$ in) of $10 \%$ DEGS on Supelcoport (50/100); carrier gas flow rate was $30 \mathrm{ml} / \mathrm{min}$ and the oven temperature was programed from $90-160^{\circ} \mathrm{C}$ at $8^{\circ} \mathrm{C} /$ min.

Enzyme assays. Cells were homogenized in $0.5 \mathrm{ml}$ of $0.25 \mathrm{M}$ sucrose $/ 1 \mathrm{mM}$ dithiothreitol/1 mM EDTA, pH 7.0, in a small glass Potter-Elvehjem homogenizer fitted with a Teflon pestle. Thioesterase II was assayed by a radiochemical procedure (32) and fatty acid synthetase by a spectrophotometric method (29). Enzyme content was calculated on a weight basis from the enzyme activities, based on the specific activities of the purified enzymes.

\section{RESULTS}

According to the literature, human milk samples have been found to contain as many as $1 \times 10^{6}$ nucleated cells per $\mathrm{ml}(3$, 10,22 ). These earlier reports indicated that the proportion of different cell types varies considerably among samples; in general, macrophages are the most abundant, accounting for $70-90 \%$ of the cells, lymphocytes account for only $1-10 \%$ and breast epithelial cells for $2-20 \%$. In a preliminary screening of 20 donors we found that the total cell content of milk samples ranged widely from $5 \times 10^{4}$ to $4 \times 10^{6}$ cells $/ \mathrm{ml}$, with a mean of $5 \times 10^{5}$ cells/ml. Employing an immunohistochemical test, which identifies specific differentiation antigens on the surface of breast epithelial cells, we confirmed earlier reports that epithelial cells accounted for less than $20 \%$ of the milk cells. Subsequent experiments were carried out with milk samples obtained from five of the donors who, fairly consistently, yielded milk samples containing relatively high numbers of epithelial cells. Even with these donors, the epithelial cell content did not exceed $20 \%$ of the total cells. By making use of a simple glass adsorption procedure, we were able to reduce markedly the proportion of macrophages in the milk cell samples. These preparations are referred to as enriched epithelial cells. A selection of typical photographs from immunohistochemical studies on the enriched epithelial cells is presented as Figure 1. The series of photographs shows cells stained indirectly for human breast epithelial cell surface antigens, human fatty acid synthetase, and human thioesterase. The latter two enzymes might be expected to play a key role in the endogenous biosynthesis of medium-chain fatty acids, were this to be an important pathway in the production of human milk fat. It should be pointed out that although the antigens used to prepare antiepithelial cell surface antibodies and antifatty acid synthetase antibodies were both of human origin, that used to raise the antithioesterase II antibodies was obtained from rat mammary gland. However, we have previously presented strong evidence indicating that these antibodies recognize specifically a human enzyme analogous to the rat thioesterase II (33). In the enriched epithelial preparations, $66 \pm 29 \%$ of the cells stained positively for the cell surface antigens, $61 \pm 21 \%$ for fatty acid synthetase, and $68 \pm 21 \%$ for thioesterase II. Over $90 \%$ of the cells were judged "viable" by the trypan blue exclusion test.

Satisfied that the procedure yielded preparations in which the predominant cell type exhibited histochemical properties consistent with their identity as breast epithelial, we initiated studies on the lipogenic pathway. Our procedure for fatty acid analysis has been developed to ensure detection of short-chain fatty acids that might be present either as free acids or as glycerides. By chromatographing the free fatty acids, rather than the commonly used volatile methyl esters, we were able to minimize losses of short-chain fatty acids. Thus we were able to demonstrate clearly, for the first time, that human milk contains trace amounts of butyric (4:0) and hexanoic (6:0) acids (Table 1). Similarly, when enriched epithelial cells were incubated with $\left[1-{ }^{14} \mathrm{C}\right]$ acetate and the products analyzed by radiochromatography of the free acids, we were able to identify radioactive $C_{4}$ and $C_{6}$ as products, albeit in small amounts. A typical radiochromatogram is shown as Figure 2. In Table 2 we have compared the rate of synthesis of fatty acids, as well as the products synthesized, by total milk cells, and enriched epithelial cells from the five selected donors.

The lipogenic rate, expressed on a per cell basis, was about 5fold higher in the enriched cells indicating that these cells are the major lipogenic cell type in human milk. Approximately $85 \%$ of the fatty acid synthesized were of chain length less than $16 \mathrm{C}$ atoms, predominantly $\mathrm{C}_{10}, \mathrm{C}_{12}$, and $\mathrm{C}_{14}$. Small, but significant, amounts of $\mathrm{C}_{4}, \mathrm{C}_{6}$, and $\mathrm{C}_{8}$ fatty acids were also synthesized. The product profiles of total milk cells and the enriched epithelial cells were quite similar, again supporting the inference that lipogenesis in the milk cell population is dominated by the contribution of the breast epithelial cells. This is entirely consistent with the fact that the contaminating cells, mainly from the
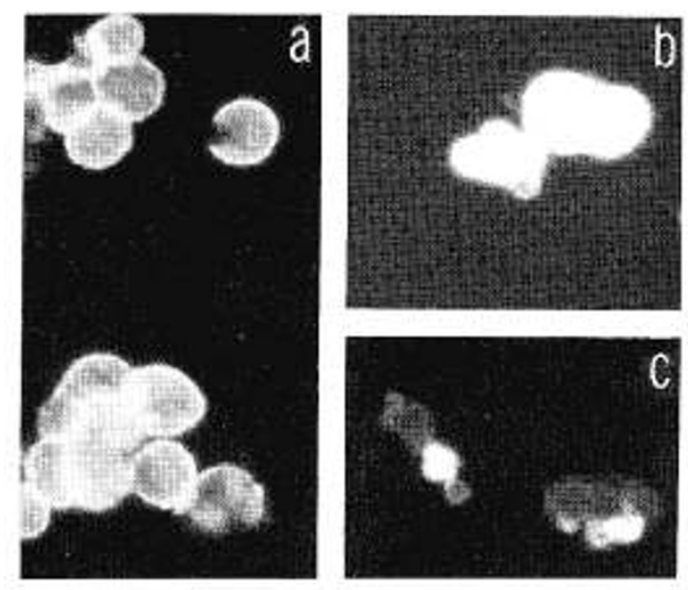

Fig. 1. Immunohistochemical characterization of breast epithelial cells obtained from human milk. First layer antibodies were: $a$, rabbit antihuman milk fat globule membrane antibodies; $b$, rabbit antihuman fatty acid synthetase antibodies; and $c$, rabbit antirat thioesterase II. 
Table 1. Fatty acid composition of human milk fat*

\begin{tabular}{cccccccccccc}
\hline $4: 0$ & $6: 0$ & $8: 0$ & $10: 0$ & $12: 0$ & $14: 0$ & $16: 0$ & $16: 1$ & $18: 0$ & $18: 1$ & $18: 2$ & $18: 3$ \\
\hline $0.2 \pm 0.1$ & $0.3 \pm 0.2$ & $1.0 \pm 0.7$ & $2.4 \pm 0.4$ & $7.8 \pm 2.3$ & $11.5 \pm 1.5$ & $21.9 \pm 3.1$ & $3.8 \pm 1.3$ & $6.4 \pm 1.8$ & $28.0 \pm 2.1$ & $16.2 \pm 6.3$ & $0.4 \pm 0.4$ \\
\hline
\end{tabular}

* Results, expressed in mol\%, are means \pm SDs from milk samples from 5 selected donors. Data were computed from gas chromatographic analysis of both free fatty acids and methyl esters. In the nomenclature used for fatty acid identification, the first number indicates the number of carbon atoms and the second number, which follows the colon indicates the number of double bonds.

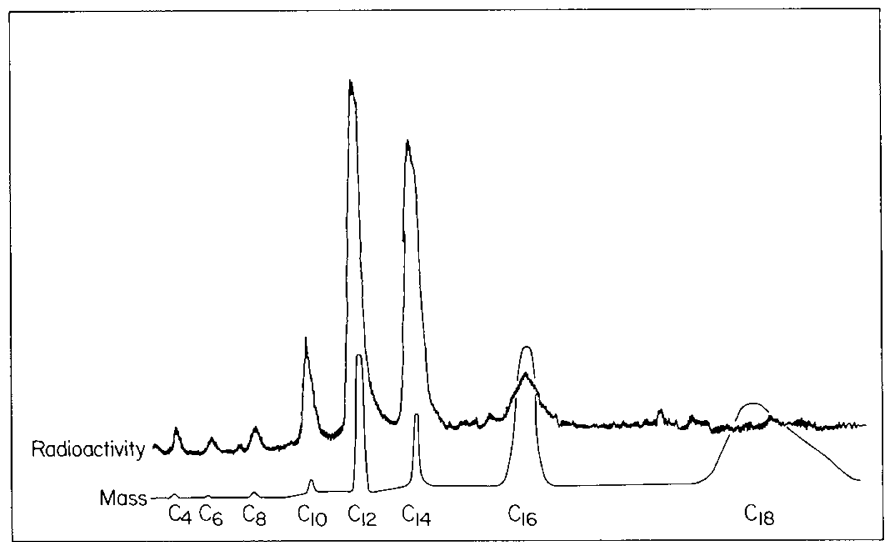

Fig. 2. Typical gas-liquid radiochromatogram illustrating chain length of fatty acids synthesized by breast epithelial cells derived from human milk. Flame ionization detector attenuation was $\times 4$ and the ratemeter was set at $3000 \mathrm{cpm}$ full scale. The elution time for $\mathrm{C}_{18}$ is approximately $1 \mathrm{~h}$. Fatty acids are identified by the number of carbon atoms present.

blood, are known to have low rates of de novo lipogenesis (16, 23). Although fatty acids of chain length $\mathrm{C}_{4}-\mathrm{C}_{14}$ were also detected as components of the milk-cell lipids (i.e. by the flame ionization detector), long-chain fatty acids predominated, accounting for approximately $70 \%$ of the fatty acids of the total milk cells and $50 \%$ of the enriched epithelial cell fatty acids. The overall fatty acid composition of the cellular elements of human milk presumably reflects the contribution of structural lipids, predominantly long-chain, as well as retained milk fat. It is not surprising therefore that the endogenous fatty acids are predominantly long-chain whereas the newly synthesized fatty acids are predominantly medium-chain.

By preparing cytosols from the enriched epithelial cells, we were able to confirm the immunohistochemical evidence for the presence of fatty acid synthetase and thioesterase II in the cells; quantitative enzymatic assays performed on these cytosols indicated values of $2.5 \pm 1.0$ and $0.023 \pm 0.006 \mu \mathrm{g} / 10^{6}$ cells for the content of fatty acid synthetase and thioesterase II, respectively.

\section{DISCUSSION}

This report constitutes the first account of some of the metabolic features of epithelial cells from the lactating human breast. Although in this study we have confined our attention to the fatty acid biosynthetic pathway, it is conceivable that epithelial cells derived from human milk could be used to study a variety of metabolic and enzymatic processes. Our results indicate clearly that the fatty acid biosynthetic pathway of the lactating human breast epithelium is devoted to the synthesis of medium-chain fatty acids; fatty acids with less than $16 \mathrm{C}$ atoms constitute over $80 \%$ of the products of de novo synthesis. In this respect the human mammary gland appears to resemble those of rats, mice, and rabbits, all of which synthesize predominantly mediumchain fatty acids. The pathway of medium-chain fatty acid synthesis also seems likely to follow a similar course in the human gland since the two key enzymes shown to be required in rats, mice, and rabbits, i.e. fatty acid synthetase and thioesterase II, are also present in the human. It may be appropriate to point out that the mechanism of medium-chain fatty acid synthesis appears to differ in ruminants and nonruminants. Mammary glands of ruminants lack the chain-terminating thioesterase II enzyme and have instead a modified fatty acid synthetase capable of transferring medium-chain acyl moieties directly to the appropriate acceptor $(8,9)$.

Although qualitatively, then, the lipogenic system of the human mammary gland appears similar to those of other nonruminants, there is a major quantitative difference. In Table 3 , we have compared some of the features of the milk fatty acid biosynthetic pathway in epithelial cells from lactating human and rat glands. First, the fat content and the percent of fatty acids $<\mathrm{C} 16$ is much lower in human than in rat milk. Thus the output of fatty acid $<\mathrm{C} 16$, expressed in $\mathrm{g} / 100 \mathrm{ml}$ is almost an order of magnitude lower in the human. Second, although both the human and rat mammary epithelial cells synthesize predominantly fatty acids $<\mathrm{C} 16$, the rate of synthesis and the content of fatty acid synthetase and thioesterase II is an order of magnitude lower in the human cells. We have considered two possible explanations for the low rate of fatty acid synthesis observed with human cells: (i) The human epithelial cells may be damaged, or may be heavily contaminated with other cell types and therefore the low rate of lipogenesis in vitro might not be representative of the true situation in vivo, or (ii) the observed low rate of fatty acid synthesis might in fact accurately reflect the status of the lipogenic pathway in the human gland. Several findings argue against the possibility that these cells may be damaged, dying, or may be of nonepithelial origin. The vast proportion of the enriched epithelial cell preparations exclude trypan blue and most stain positively for the breast epithelial cell surface markers as well as the breast epithelial cytosol marker, thioesterase II. Furthermore, these cells have been successfully cultured by a number of investigators $(3,5,12,17,26,27,34)$. The implications of the second possibility are of considerable interest. The fact that fatty acids $<\mathrm{C} 16$ are present in human milk at a much lower concentration than in rat milk is quite consistent with our observation that the rate of synthesis of these fatty acids is much lower in mammary epithelial cells of the human than in those of the rat. Since human breast epithelial cells do not appear to synthesize significant amounts of long-chain fatty acids, the predominant fatty acids of human milk, it follows that the overall contribution of endogenous mammary gland fatty acid synthesis to the production of human milk fat is probably quite low (perhaps only about $20 \%$ ) compared with that of the rat (perhaps about 50\%).

The proportion of medium-chain fatty acids in the milk of our donors is similar to that reported by other investigators for women ingesting typical Western diets. However, it was shown in 1959 that changes in the fatty acid composition of human milk can be induced by alterations in diet (11). This would seem to be an appropriate time to reevaluate the significance of these earlier observations. Insull et al. (11) provided a human subject with two experimental isocaloric diets, one containing $70 \%$ of the calories as corn oil, the other containing less than $1 \%$ of the calories as fat. The total milk fat production was similar when the subject was fed the two diets, about 24-30 g/day. Unfortunately, fatty acids of chain length $<\mathrm{C} 12$ were not measured in that study. Nevertheless, it is clear that the content of $C_{12}$ and $\mathrm{C}_{14}$ fatty acids in the milk was more than 6-fold higher when the subject was fed the low-fat rather than the high-fat diet. If, as our present study indicates, these medium-chain fatty acids are syn- 
Table 2. Fatty acids synthesized by cells derived frm human milk*

\begin{tabular}{|c|c|c|c|c|c|c|c|c|c|c|c|c|c|c|c|c|c|}
\hline \multirow[b]{2}{*}{ Cells } & \multirow{2}{*}{$\begin{array}{c}\text { Lipogenic } \\
\text { rate } \\
\left(\mathrm{nmol} / \mathrm{h} / 10^{6}\right. \\
\text { cells) }\end{array}$} & \multicolumn{8}{|c|}{ mol\% fatty acids synthesized } & \multicolumn{8}{|c|}{ mol\% fatty acids present } \\
\hline & & $\mathrm{C}_{4}$ & $\mathrm{C}_{6}$ & $\mathrm{C}_{8}$ & $\mathrm{C}_{10}$ & $\mathrm{C}_{12}$ & $\mathrm{C}_{14}$ & $\mathrm{C}_{16}$ & $\mathrm{C}_{18}$ & $\mathrm{C}_{4}$ & $\mathrm{C}_{6}$ & $\mathrm{C}_{8}$ & $\mathrm{C}_{10}$ & $\mathrm{C}_{12}$ & $\mathrm{C}_{14}$ & $\mathrm{C}_{16}$ & $\mathrm{C}_{18}$ \\
\hline $\begin{array}{l}\text { Total milk } \\
\text { cells }\end{array}$ & $0.19 \pm 0.19$ & $\begin{array}{r}1.0 \\
\pm 2.3\end{array}$ & $\begin{array}{r}2.5 \\
\pm 4.3\end{array}$ & $\begin{array}{r}4.9 \\
\pm 5.8\end{array}$ & $\begin{array}{r}18.3 \\
\pm 10.1\end{array}$ & $\begin{array}{r}36.3 \\
\pm 8.9\end{array}$ & $\begin{array}{r}22.1 \\
\pm 6.1\end{array}$ & $\begin{array}{r}13.1 \\
\pm 13.3\end{array}$ & $\begin{array}{r}1.8 \\
+4.0\end{array}$ & $\begin{array}{r}2.2 \\
\pm 2.1\end{array}$ & $\begin{array}{r}2.4 \\
\pm 1.6\end{array}$ & $\begin{array}{r}3.1 \\
\pm 4.7\end{array}$ & $\begin{array}{r}4.0 \\
\pm 4.9\end{array}$ & $\begin{array}{r}9.3 \\
\pm 5.1\end{array}$ & $\begin{array}{r}10.4 \\
\pm 3.9\end{array}$ & $\begin{array}{r}26.9 \\
\pm 6.0\end{array}$ & $\begin{array}{r}41.7 \\
\pm 12.6\end{array}$ \\
\hline $\begin{array}{l}\text { Enriched } \\
\text { epithelial } \\
\text { cells }\end{array}$ & $1.1 \pm 0.8$ & $\begin{array}{r}1.0 \\
\pm 2.1\end{array}$ & $\begin{array}{r}2.3 \\
\pm 4.0\end{array}$ & $\begin{array}{r}3.6 \\
\pm 3.2\end{array}$ & $\begin{array}{r}11.9 \\
\pm 1.0\end{array}$ & $\begin{array}{r}35.0 \\
\pm 6.2\end{array}$ & $\begin{array}{r}30.0 \\
\pm 6.9\end{array}$ & $\begin{array}{r}14.4 \\
\pm 6.0\end{array}$ & $\begin{array}{r}1.8 \\
\pm 1.7\end{array}$ & $\begin{array}{r}1.0 \\
+1.7\end{array}$ & $\begin{array}{r}2.0 \\
\pm 3.0\end{array}$ & $\begin{array}{r}6.8 \\
\pm 7.3\end{array}$ & $\begin{array}{r}10.0 \\
\pm 4.3\end{array}$ & $\begin{array}{r}13.5 \\
\pm 1.7\end{array}$ & $\begin{array}{r}15.5 \\
\pm 2.5\end{array}$ & $\begin{array}{r}20.9 \\
\pm 8.2\end{array}$ & $\begin{array}{r}30.3 \\
\pm 11.7\end{array}$ \\
\hline
\end{tabular}

* Values represent means \pm SDs for milk samples obtained from five different donors. Fatty acids are identified by the number of carbon atoms present; see footnote Table 1 .

Table 3. Comparison of the lipogenic characteristics of epithelial cells from mammary glands of lactating humans and rats

\begin{tabular}{|c|c|c|c|c|c|c|c|}
\hline Species & $\begin{array}{l}\text { Milk fat } \\
(\mathrm{g} / 100 \mathrm{ml})\end{array}$ & $\begin{array}{l}\% \mathrm{C}_{4}-\mathrm{C}_{14} \\
\text { in milk fat }\end{array}$ & $\begin{array}{c}\mathrm{C}_{4}-\mathrm{C}_{14} \text { acids } \\
\text { secreted in } \\
\text { milk } \\
(\mathrm{g} / 100 \mathrm{ml}) \\
\end{array}$ & $\begin{array}{c}\% \mathrm{C}_{4}-\mathrm{C}_{14} \\
\text { synthesized by } \\
\text { epithelial cells }\end{array}$ & $\begin{array}{c}\text { Lipogenic rate } \\
\text { of cells } \\
\text { (nmol acetate/ } \\
10^{6} \text { cells } / \mathrm{h} \text { ) }\end{array}$ & $\begin{array}{c}\text { Fatty acid } \\
\text { synthetase } \\
\left(\mu \mathrm{g} / 10^{6} \text { cells }\right)\end{array}$ & $\begin{array}{l}\text { Thioesterase } \\
\left(\mu \mathrm{g} / 10^{6} \text { cells }\right)\end{array}$ \\
\hline Human* & 4.5 & 23 & 1.0 & 84 & 1.1 & 2.6 & 0.03 \\
\hline Rat $\dagger$ & 15.0 & 52 & 7.8 & 87 & 25 & 20 & 0.5 \\
\hline
\end{tabular}

* Data from this paper. The $\% \mathrm{C}_{4}-\mathrm{C}_{14}$ in milk fat is taken from Table 1 and the amount of $\mathrm{C}_{4}-\mathrm{C}_{14}$ secreted is calculated from data in columns one and two of this table. The $\% \mathrm{C}_{4}-\mathrm{C}_{14}$ synthesized and the lipogenic rate are taken from Table 2 .

$\dagger$ Data from References 6 and 28.

thesized by the mammary epithelial cells, then it would seem that the fatty acid synthesizing system of the human breast may be an adaptive one which can be repressed by maternal diets high in fat. This question, whether or not the fatty acid synthesizing system of lactating mammary glands is adaptive to dietary changes, is a controversial issue. Romsos et al. (25) and Grigor and Warren (7) have claimed that the system in rats and mice is indeed affected by dietary fat, whereas Smith et al. (30) have suggested that this may not be the case. The first two groups assessed mammary lipogenic rates by injection of ${ }^{3} \mathrm{H}_{2} \mathrm{O}$ in vivo and it is unclear whether these workers considered the possibility that some of the radioactive fatty acids found in the mammary gland may have been synthesized in, and transported from, the liver. Indeed one of these groups has been unable, thus far, to substantiate their prediction that the observed changes in lipogenic activity would ultimately be shown to result from changes in the activities of key mammary lipogenic enzymes; this group (6) found the mammary fatty acid synthetase content to be unaltered by changes in maternal diet, an observation consistent with the original findings of Smith et al. (30). Clearly further experimentation is needed to clarify this issue. With the introduction of a procedure for assessing lipogenic rates in lactating human breast epithelial cells, it ought to be possible to tackle this problem with human, as well as animal subjects.

The results of this and earlier studies raise the possibility that the lipogenic system of the human breast is an adaptive one which can be repressed by maternal diets high in fat, and fully expressed on consumption of low fat, high carbohydrate diets. If we accept that, during evolution, retention of the ability to synthesize these unique fatty acids offered some selective advantage in neonatal nutrition, perhaps the wisdom of repressing this lipogenic system, by consumption of high fat diets, ought to be carefully evaluated.

Acknowledgments. We are grateful to Dr. Roberto Ceriani for supplying us with the rabbit anti-human milk fat globule membrane antibodies.

\section{REFERENCES}

1. Abraham S, Kerkof PR, Smith S 1972 Characteristics of cells dissociated from mouse mammary glands. II. Metabolic and enzymatic activities of parenchymal cells from lactating glands. Biochim Biophys Acta 261:205
2. Agradi $\mathrm{E}$, Smith $\mathrm{S} 1976$ The influence of $\mathrm{pH}$ on the partial reactions of the fatty acid synthetase multienzyme: modification of product specificity. Int $\mathbf{J}$ Biochem 7:467

3. Buehring GC 1972 Culture of human mammary epithelial cells: Keeping abreast of a new method. J Natl Cancer Inst 49:1433

4. Ceriani RL, Thompson K, Peterson JA, Abraham S 1977 Surface differentiation antigens of human mammary epithelial cells carried by the human milk fat globule. Proc Natl Acad Sci USA 74:582

5. Furmanski P, Longley C, Fouchey D, Rich R, Rich MA 1974 Normal human mammary cells in culture: Evidence for oncornavirus-like particles. J Natl Cancer Inst 52:975

6. Grigor MR, Guersen A, Sheyd MJ, Warren SM 1982 Regulation of lipogenic capacity in lactating rats. Biochem $\mathrm{J} 208: 611$

7. Grigor MR, Warren SM 1980 Dietary regulation of mammary lipogenesis in lactating rats. Biochem $\mathrm{J}$ 188:61

8. Grunnet I, Knudsen J 1979 Fatty acid synthesis in lactating goat mammary gland. 1. Medium chain fatty acid synthesis. Eur J Biochem 95:497

9. Grunnet I, Knudsen J 1979 Fatty acid synthesis in lactating goat mammary gland. 2. Medium chain fatty acid synthesis. Eur J Biochem 95:503

10. Holquist DG, Papanicolaou GN 1956 Exfoliative cytology of mammary gland during pregnancy and lactation. Ann NY Acad Sci 63:1422

11. Insull W Jr, Hirsch J, James T, Ahrens EH Jr 1959 The fatty acids of human milk. Il. Alterations produced by manipulation of caloric balance and exchange of dietary fats. $\mathbf{J}$ Clin Invest 38:443

12. Kirkland WL, Yang N-S, Jorgensen T, Longley C, Furmanski P 1979 Growth of normal and malignant human mammary epithelial cells in culture. J Nat! Cancer Inst 63:29

13. Knudsen J, Clark S, Dils R 1976 Purification and some properties of a medium chain hydrolase from lactating-rabbit mammary gland which terminates chain elongation in fatty acid synthesis. Biochem J 160:683

14. Libertini LJ, Smith S 1978 Purification and properties of a thioesterase from lactating rat mammary gland which modifies the product specificity of the fatty acid synthetase. J Biol Chem 253:1393

15. Libertini LJ, Smith S 1979 Synthesis of long chain acyl-enzyme thioesters by modified fatty acid synthetases and their hydrolysis by a mammary gland thioesterase. Arch Biochem Biophys 192:47

16. Majerus PW, Lastra R 1967 Fatty acid biosynthesis in human leukocytes. J Clin Invest 46:1596

17. McKay IA, Taylor-Papadimitriou J 1981 Junctional communication pattern in cells cultured from human milk. Exp Cell Res 134:465

18. Metcalfe LD, Schmitz AA, Pekla JR 1966 Rapid preparation of fatty acid esters from lipids for gas chromatographic analysis. Anal Chem 38:514

19. Nolin JM. Thompson BJ, Smith S 1982 Localization of thioesterase II, the chain-length regulatory enzyme of milk fatty acid synthesis, in rat mammary gland epithelial cells. J Endocrinol 94:251

20. Pasco D, Quan A, Smith S, Nandi S 1982 Effect of hormones and EGF on proliferation of rat mammary epithelium enriched for alveoli, an in vitro study. Exp Cell Res 141:313

21. Pitelka DR, Kerkof PR, Gagne HT, Smith S, Abraham S 1969 Characteristics of cells dissociated from mouse mammary glands: I. Method of separation and morphology of parenchymal cells from lactating glands. Exp Cell Res $57: 43$

22. Pittard WB, Bill K 1981 Human milk banking; effect of refrigeration on 
cellular components. Clin Pediatr 20:31

23. Pittman JG, Martin DB 1966 Fatty acid biosynthesis in human erythrocytes. J Clin Invest 45:165

24. Radin NS 1981 Extraction of tissue lipids with a solvent of low toxicity. In: Lowenstein JM (ed) Methods in Enzymology, Vol 72, Academic Press, New York, p 5-7

25. Romsos DR, Miururi KL, Lin P-Y, Leveille GA 1978 Influence of dietary fat, fasting and acute premature weaning on in vivo rates of fatty acid synthesis in lactating mice. Proc Soc Exp Biol Med 159:308

26. Russo J, Furmanski P, Bradley R 1976 Differentiation of normal human mammary epithelial cells in culture: an ultrastructural study. Am $\mathbf{J}$ Anat 145:57

27. Russo J, Furmanski P, Rich MA 1975 An ultrastructure study of normal human mammary epithelial cells in culture. Am J Anat 142:221

28. Smith S 1980 Mechanism of chain length determination in biosynthesis of milk fatty acids: a review. J Dairy Sci 63:337

29. Smith S 1981 Long-chain fatty acyl-S-4'-phosphopantetheine-fatty acid syn- thase thioester hydrolase from rat in: Lowenstein JM (ed) Methods in Enzymology, Vol 71, Academic Press. New York, p 181-188

30. Smith S, Gagne HT, Pitelka D, Abraham S 1969 The effect of dietary fat on lipogenesis in mammary gland and liver from lactating and virgin mice. Biochem J 115:807

31. Smith S, Libertini LJ 1979 Specificity and site of action of a mammary gland thioesterase which releases acyl moieties from thioester linkage to the fatty acid synthetase. Arch Biochem Biophys 196:88

32. Smith S, Pasco D, Nandi S 1983 Biosynthesis of medium-chain fatty acids by mammary epithelial cells from virgin rats. Biochem $J$ 212:155

33. Smith S, Pasco D, Pawlak J, Thompson BJ, Stampfer M, Nandi S 1984 Thioesterase II, a new marker enzyme for human cells of breast epithelial origin. J Natl Cancer Inst 73:323

34. Taylor-Papadimitriou J, Shearer M, Tilley R 1977 Some properties of cells cultured from early-lactation human milk. J Natl Cancer Inst 58:1563

35. Thompson BJ, Stern A, Smith S 1981 Purification and properties of fatty acid synthetase from a human breast cell line. Biochim Biophys Acta 662:125

\title{
Surfactant Treatment and Ventilation by High Frequency Oscillation in Premature Newborn Rabbits: Effect on Survival, Lung Aeration, and Bronchiolar Epithelial Lesions
}

\author{
ROLAND NILSSON, PER BERGGREN, TORE CURSTEDT, GERTIE GROSSMANN, \\ GUNNAR RENHEIM, AND BENGT ROBERTSON \\ Departments of Pediatric Pathology and Pediatrics, St. Görans Hospital, Stockholm, Department of Clinical \\ Chemistry, Karolinska Hospital, Stockholm, and Ventilator Division, Research and Development Department,
} Siemens-Elema, Solna, Sweden

\begin{abstract}
Premature rabbit neonates delivered at gestational age 27 days were ventilated by high frequency oscillation for $60 \mathrm{~min}$ with $100 \% \mathrm{O}_{2}$, using a frequency of $7-8 \mathrm{~Hz}, 50 \%$ inspiration time and mean airway pressures of $6-8 \mathrm{~cm} \mathrm{H}_{2} \mathrm{O}$. Twenty-five animals received bovine surfactant $(2 \mathrm{ml} / \mathrm{kg}$ body weight; phospholipid concentration $85-100 \mathrm{mg} / \mathrm{ml}$ ) in the tracheal cannula before onset of ventilation, and 22 littermates served as controls. In the surfactant-treated group, average tidal volume was about 10 times larger than in controls, yet only $15 \%$ of the estimated dead space. Judged from ECG recordings, the treated animals also had a much higher survival rate: 96 versus $5 \%(p<0.001)$. Morphometrically, mean alveolar volume density was increased in the surfactant-treated animals in comparison with controls: $0.65 \pm 0.08$ versus $0.37 \pm 0.08(\overrightarrow{\mathrm{x}} \pm \mathrm{SD} ; p<0.005)$. Bronchiolar epithelial lesions were found in all control animals and were severe in almost all cases. In the surfactant-treated group, epithelial lesions were absent in 12 , mild in 11 , and fairly prominent in two animals. We conclude that after treatment with surfactant, the premature newborn rabbit can be
\end{abstract}

Received May 10, 1984; accepted August 20, 1984.

Requests for reprints should be addressed to Roland Nilsson, M.D., Department of Pathology, St. Görans Hospital, S-112 81 Stockholm, Sweden.

This work was supported by the Swedish Medical Research Council (Project 3351), the Swedish National Association against Heart and Chest Diseases, the "Expressen" Prenatal Research Foundation, the Research Funds of the Karolinska Institute, and Allmänna Barnbördshusets Minnesfond. ventilated adequately with high frequency oscillation at comparatively low mean airway pressures and that surfactant replacement effectively reduces the development of epithelial lesions in conducting airways during high frequency oscillation. (Pediatr Res 19: 143-147, 1985)

\section{Abbreviations}

HFO, high frequency oscillation

$V_{T}$, tidal volume

$V_{v}$, volume density

The tendency of the surfactant-deficient lung to collapse at end-expiration can be compensated for by a variety of therapeutic measures, such as the application of continuous positive airway pressure (3) or the adjustment of respiratory rate and inspiration/ expiration ratio during artificial ventilation (6). Recent data from animal experiments and clinical trials indicate that ventilation by $\mathrm{HFO}$ might represent yet another realistic alternative (for review, see Refs. 1 and 5). During HFO, the lungs are kept expanded by the pressure needed to maintain uniform air expansion, while ventilation is provided by oscillatory movements involving tidal volumes smaller than the dead space of the airways. Gas exchange probably occurs by a combination of convection and diffusion, referred to as "augmented transport" (12). 